\section{LARK BUNTING IN NORTHEASTERN ALBERTA}

ALAN J. KENNEDY, Canadian Wildlife Service, Room 1000, 9942 108th Street, Edmonton, Alberta, T5K $2 \mathrm{~J} 5$.

On 20 September 1979, a male Lark Bunting was seen near Fort McMurray, Alberta (Figure 1). This species breeds from the southern Prairie Provinces (see Figure 1) to New Mexico and Texas. ${ }^{2}$ It is considered a casual resident in southern Alberta, Saskatchewan, and Manitoba.' Previous northern site records are from: Vegreville and Beaverhill Lake, Alberta; Prince
Albert and Regina, Saskatchewan; and Brandon, Manitoba. ${ }^{2}$

The bird reported here was observed flying on the southeastern shore of Ruth Lake (56 $56^{\circ} \mathrm{N}, 111^{\circ} 9^{\prime}$ W) approximately $44.8 \mathrm{~km}(28.0 \mathrm{mi}$.) north of Fort McMurray, Alberta. E. Butterworth and I sighted it twice on 20 September. I observed it again on 25 September. Both sightings were at the same location.

These records represent a $400 \mathrm{~km}$ (250 mi.) extension to the known range of this species. Observation of this species late in the fall is also rare.

These sightings were made while conducting bird surveys for Syncrude Canada Ltd. I appreciate the assistance given by Syncrude personnel in completing this note.
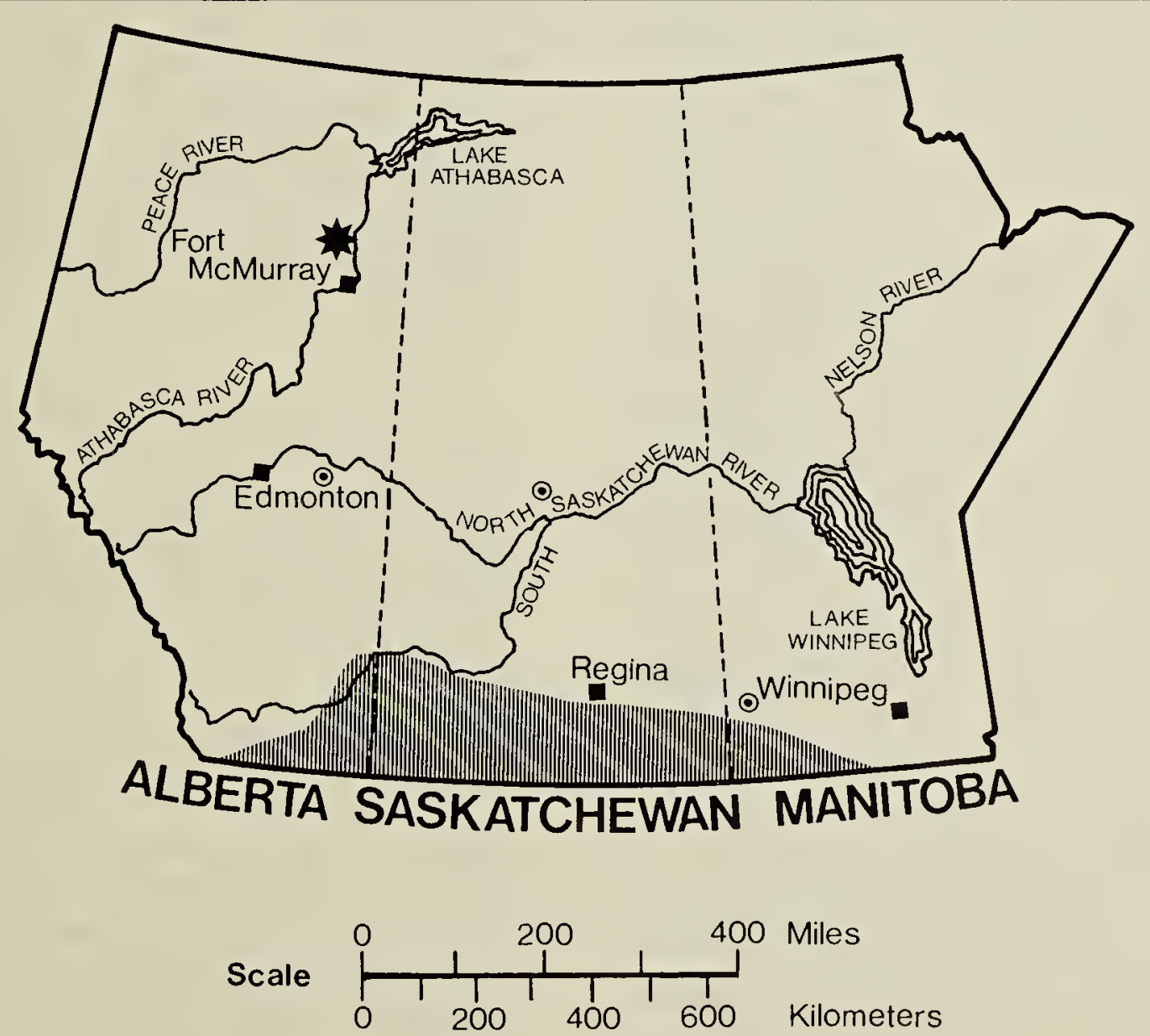

Breeding Range of Lark Bunting $\odot$ Previous Sightings (Salt and Salt 1976)

Figure 1. Distribution of Lark Bunting on prairie provinces showing range extension. 
'GODFREY, W. E. 1966. The birds of Canada. National Museum of Canada. Bull. 203. Ottawa. 428 pp.

'SALT, W. R. and J. R. SALT. 1976. The birds of Alberta. Hurtig, Edmonton. $498 \mathrm{pp}$.

\section{LAZULI BUNTING AND ROCK WREN AT SYLVAN LAKE, ALBERTA}

HELGE S. ABRAHAMSON, Box 268, Sylvan Lake, Alberta, TOM 1 ZO.

Living at Sylvan Lake on NE 39-2W5, I have for more than 40 years been active with bird observations. In July 1967 I sighted a blue bird that was much different from the Mountain Bluebird. I looked it up in my bird book and concluded it was a male Lazuli Bunting. Three days went by before the bird left the deciduous, scrubby growth which surrounded my house. Then in 1971 I saw one by my house in the same area as the first sighting. This same day another Lazuli Bunting was seen at the Scout Camp, a mile and a half from my house. This indicated that there were more than one of these birds in the area. No sighting of the female was made.

The Blue Jay of September 1979 contained an article "The Rock Wren in Saskatchewan" which was quite interesting. This is also an unusual bird of my area according to my bird book, "Birds of North America" by Robbins, Bruun and Zim. In 1972, along a rocky shoreline with sandstone cliffs on a stretch of Sylvan Lake beach, I observed a pair of these birds and found their nest in early July. I haven't been back to this particular area. Where I live on the southern edge of this lake, I have never observed any Rock Wrens.
MOCKINGBIRDS AT RESTON, MANITOBA

DAVID L. BRADDELL, Box 304 Reston, Manitoba, ROM $1 \mathrm{XO}$.

On 1 August, 1979, in response to a phone call from Bob Moore, loca building contractor, I checked out a bird of unusual imitative ability and a long tail.

At Third Avenue and Eighth Stree in Reston, I observed a bird perchec on the top of Bryon Jago's TV anten na. Its flicking, long, dark tail, slende gray and whitish body, and its im itation of the songs or calls of fou species of other birds suggested $i$ could be a Mockingbird. While I was observing the bird, using 10) binoculars, it flew down from its perch and displayed a prominen white patch on each wing. In landing on a nearby lawn, the bird raised its wings and tail briefly, revealing white wingbars and patch, and lateral white edging to the tail. A slightly down curving bill and pale eyes were evident.

Later the same day, Mr. Moor reported having seen two such bird: simultaneously, one on a hydro line the other on a TV antenna two block away. They were imitating other bird but differently from one another, $h$ said.

On 31 July, one of these birds wa heard by Evan Ellis and Mrs. W. A Elliott, and was seen 1 August by $M$ Moore, myself and several other per sons. Mr. Ellis stated he had seen th bird fly down more than once to ge raspberries from the garden nex door.

On 3 August, Bryon Jago repor ed two mockers, having heard an seen one on a TV antenna, and ther only a moment later, heard anothe 